\title{
СИМВОЛІЧНЕ НАВАНТАЖЕННЯ ЛЕКСЕМ «МІСЯЦЬ» І «ЗОРЯ» В ПОЕТИЧНИХ ТЕКСТАХ ІВАНА ФРАНКА
}

Явір Л. В. Символічне навантаження лексем «місяць» і «зоря» в поетичних текстах Івана Франка.

У статті на матеріалі поезій Івана Франка досліджено й проаналізовано символічне навантаження лексем «місяць» $\mathrm{i}$ «зоря». На конкретних прикладах проілюстровано вживання вказаних лексем у різних символічних смислах, що засвідчує глибоку ерудицію Івана Франка, його майстерний поетичний хист. символіка.

Ключові слова: символ, лексема, сема, астральна символіка, космологічна

Явир Л. В. Символическая нагрузка лексем «луна» и «звезда» в стихах Ивана Франко.

В статье исследована и проанализирована символическая нагрузка лексем «луна» и «звезда» в поэтических текстах Ивана Франко. На конкретных примерах иллюстрируется функционирование указанных лексем в различных символических смыслах, что свидетельствует о глубокой эрудированности Ивана Франко, его безупречном таланте.

Ключевые слова: символ, лексема, сема, астральная символика, космологическая символика.

Yavir L. V. The symbolic meanings of the terms «moon» and «star» in Ivan Franco's poetry.

The article deals with the symbolical meaning of the terms moon and star in Ivan Franco's poetry. By using the specific examples we have illustrated the functioning of these terms in various symbolical meanings, which proves the author's deep erudition, his perfect poetical talent.

Key words: symbol, lexeme, seme, astral symbolism, cosmological symbolism.

«Франко талант дуже ріжнородний і дуже багатий, нема такого роду письменницьких форм, яких він не вживав би, нема таких родів літературних творів, у яких він не пробував би свойого пера, і що важніше - не пробував того пера $з$ таким великим успіхом» [9, с. 22].

«Франко належить у нас до типу письменників-універсалістів, як ось Куліш, Кониський, Грінченко, письменників із дуже широкими культурними, політичними, громадськими інтересами. Через те така 
широка й ріжноманітна його діяльність. I як обхопити їі цілу, то не знати, чому дати першенство. Чи Франко більший письменник, чи вчений, чи публіцист, чи громадський діяч. I в письменстві - чи його характеризує суб'єктивна поезія, чи більший у нього епічний талант, психольог він чи рефлєксист, чи вдається йому краще вірш, чи оповідна форма, чи новеля його поле діяльности, чи лірика. Одне тільки певне, що краще у нього виходить оповідання, ніж повість, ліпша, знов повість, ніж драма» [9, с. 102].

У своїй невеличкій розвідці зупинимося на дослідженні поетичної робітні Івана Франка, а точніше на аналізі символічного наповнення лексем «місяць» $\mathrm{i}$ «зоря» в поетичних творах митця.

Поетична творчість Івана Франка організовується «певними темами, ліричними сюжетами, наскрізними мотивами; у його творчості виявляється постійне звернення до тих самих мовних одиниць, улюблених стилістичних прийомів тощо. Саме на цьому формуються особливі риси його поетичного ідіостилю. Найважливішими тут $\epsilon$ наскрізні образи, що розуміються як багаторазово повторювані в різному контекстуальному оточенні слова, значення яких у творчості даного автора стають стійкосимволічними, які служать засобом втілення найбільш значущих тем, мотивів, $\epsilon$ ядром функціонально-семантичного поля, утвореного атрибутами (асоціатами) наскрізного образу, його дериватами, постійними епітетами тощо» [6, с. 257].

Символи - це одна із найбільш облюбованих струн поетичної ліри Івана Франка. Вони допомагають краще передати універсалізм художнього мислення митця, феноменальні властивості його поетичного слова.

На перший погляд вірші поета повністю витримані в дусі автологізму. Але, коли розгледіти їх ближче, то відкривається зовсім інша картина. Поезії Івана Франка перенасичені символами, і цим він підтверджує власну думку про те, що в поезії кожне слово може бути символом.

Мовознавство рясніє чисельними розвідками, що присвячені теорії дослідження символу. Це фундаментальні праці Х. Керлота, Е. Кассірера, С. Аверинцева, О. Лосєва, К. Юнга та ін. Серед українських дослідників варто виділити імена В. Кононенка, В. Жайворонка, М. Дмитренка, О. Потапенка та ін. Однак спеціальних досліджень присвячених лінгвостилістичним аспектам символів у поезіях Івана Франка, на жаль, немає. Тому вважаємо цю проблему 
актуальною та перспективною.

У нашій статті зупинимося на аналізі астральних символів «місяць» і «зоря» у поетичній творчості Івана Франка. Мета статті виокремити в поезіях I. Франка лексеми «місяць» і «зоря», ужиті у власне символічному значенні; дослідити й проаналізувати їх символічне наповнення.

Теорія символу має свою тривалу історію вивчення і тягнеться ще 3 античних часів. Однак і дотепер викликає багато суперечок та розбіжностей. Більшість дослідників сходяться на тому, що символ це образ, узятий в аспекті своєї знаковості, i що він $\epsilon$ знаком, наділеним усією органічністю та невичерпною багатозначністю образу.

Особливістю символу як мовної одиниці є множинність значень, що виявляють себе в різних контекстах, ситуаціях, поєднання i взаємодія цих значень завдяки аналогії й асоціативним зв'язкам [6, с. 141].

Існують і різні підходи до класифікації символів. У своїй статті спиратимемося на класифікацію В. Кононенка. Дослідник виділяє такі групи символів: архетипні, біблійні, космологічні, символізація назв явищ природи, рослинні, символізація назв істот, символізація предметних назв. Об’єктом нашого зацікавлення виступають космологічні слова-символи, а конкретніше - «місяць» і «зоря».

Більшість дослідників символічної структури лексем «місяць» $\mathrm{i}$ «зоря» сходяться на тому, що ці символи досить багатозначні та багатогранні. Іван Франко своєю поетичною творчістю не просто підтвердив це, а й розширив спектр семантичних прирощень названих символів.

«Місяць» i «зоря» репрезентують сферу космологічної (у вужчому розумінні - астральної) символіки. Культ космологічних (астральних) предметів і явищ - землі, сонця, місяця, зірок, неба, землі тощо - пов'язаний iз давніми язичницькими віруваннями наших предків. Незнання їх природи й походження створювало передумови для виникнення міфів, легенд, казок, фантастичних оповідей, для відправи обрядів і ритуалів, присвячених цим божествам. Пізніше опоетизоване витлумачення сутності космологічних предметів і явищ мало в своїй основі персоніфікацію - наділення їх властивостями живих істот. Водночас попри існування загальновизначених поетичних образів-символів, на грунті народних уявлень про космологічні явища розвинулась система національних традицій 
символізації [6, с. 167].

В. Кононенко виділяє у структурі символу «місяць» семантичні компоненти «Божа сила», що визначає життя і смерть людини, добрий знак, показник сприятливих обставин [6, с. 167]. «Зоря» ж виступає носієм чиєїсь душі (зі смертю людини їі зірка згасає). Зоря - символом коханої, близької людини. Компоненти символічного значення «доля», «щастя», «вдача», «мрія», «надія», «сум», «дівчина» [6, с. 171].

В. Жайворонок акцентує на тому, що місяць здавна був об'єктом релігійного поклоніння, до якого зверталися в замовляннях. 3 культом місяця пов’язано безліч вірувань. Скажімо, люди вважали, що перед молодим місяцем треба перехреститися, щоб щастило, а повний місяць впливає на людину. У народнопісенній традиції місяць уособлює коханого або ж його вірного супутника, що осяває дорогу від чи до милої. Місяць і вечорова зоря - символи молодого і молодої. 3 місяцем здавна пов'язують розвиток рослин і стан здоров'я людей, їню фізичну красу [3, с. 369].

Зорі в народі здавна символізували святих i праведних, що супроводжують людину від народження й до смерті. Це вікна, у які боги виглядають на світ i через які влітають душі померлих. У фольклорі зорі - сонцеві і місяцеві діти, пізніше Божі очі; кожна людина має на небі свою зірку, і коли вона народжується, Бог запалює зірку, а коли вмирає, з неба котиться й зірка. У народних піснях зірка, що падає, символізує також журбу, горе, біду, смерть. Водночас зірка символ яскравого світла, краси взагалі, гарної дівчини [3, с. 254].

Х. Керлот наголошує, що символізм лексеми місяць надзвичайно об'ємний і складний. Він розглядає «місяць» як символ змін, переродження, мінливості. Пояснює свій погляд тим, що місяць змінює форму - півмісяць виростає до повного місяця, повний місяць помирає і знову народжується півмісяць. Десь тут присутній і аспект страждання, загибелі, смерті. Однак заперечується тлумачення смерті як припинення існування. Смерть - це час змін. Місяць вважають i покровителем жінок. Зміна місяцем своєї форми аналогічна змінам пір року і віку людини, а це засвідчує, що місяць виступає символом росту людини (юність - зрілий вік) і іiі занепаду (зрілість - старість) [4, с. 296-300].

Своєрідний погляд дослідник висловив і про символ зоря, що уособлює просвітлення, поєднання духу й матерії, а інколи навіть сили зла. Зоря, за Х. Керлотом, - це символ світла, що сяє в темряві, символ духу. Символізм зорі асоціюється з ніччю [4, с. 206]. 
М. Дмитренко акцентує на тому, що в народному світогляді $є$ поняття, без яких не обходиться жодна людина протягом усього життя, за якими вона звіряє за ними свою долю. До таких основних світотворчих начал належить місяць. Закорінений у давні міфологічні пласти, образ місяия символізував життя, світло, любов, постійне оновлення, безсмертя, вічність, чоловіче і жіноче начало - МатірВелику Богиню, Царицю Небесну; князя, парубка, козака, нареченого. Місяць - це «нічне Боже око», «козацьке сонце» («циганське сонце»), «відьомське око», «злодійське око». Крім того, місяць - символ пустелі, вола, качки, гуски, залежно від форми - серпа, чаші, повноти, надщербності тощо. Отже, місящь символізував позитивне й негативне начала, початок і кінець, приплив і відплив, ріст і вмирання. Люди вірили в місяць як у всесильну істоту, що може вплинути на майбутню долю. Цю віру відображено в народних піснях, замовляннях, у місяця просили звичайного життєвого сприяння [2, с. 108-112].

Зорю ж дослідник розглядає як символ жіночого божества світла, вічності, животворної природи, довершеної краси, таємниці, любові, багатства, мрії. Це - ідеальний символ дівчини, жінки; зірки символізують також янголів, дітей, свічки, живі (або померлі) душі тощо. Зоря-зоряниця - сестра Сонця, символ Великої Богині, яка дарує світло й постійно бореться супроти темряви [2, с. 113].

Іван Франко в художній формі не просто висвітлив різні семантичні грані аналізованих символів, а розширив та збагатив їх структуру.

Найпоширеніший символічний обертон лексеми «місяць» у поезії митця - світло, що проганяє пітьму. Таке бачення є наскрізним у вірші «Місяцю-князю». Символічним у цій поезії виступає вже сам апелятив «князю», що цілком витриманий у дусі фольклорної традиції. Це звертання відображено в багатьох народних замовляннях, що виникали 3 різного приводу. Але здебільшого в місяця випрошували звичайного життєвого сприяння: Місяц̧ю-князю! Нічкою темною Тихо пливеш ти Стежков таємною... [10, с. 120].

Образ місяия в народі часто асоціювався з усесильною істотою, що може вплинути на майбутню долю [2, с. 109]. Іван Франко не залишався осторонь таких міркувань. Він теж звертається до місяця 3 проханням відвернути біду від рідного народу. А тим самим розгортає його семантичне поле аж до символу глибоко національного, патріотичного. Однак доходить до сумного висновку, що «людськости бідної горе безсонне» вже досягло меж «бездонного моря». Навіть 
всесильний місяць тут безвладний і окутується смутком: Місяц̧ю-князю, Tu, чарівниченьку! Смуток на твойому Ясному личеньку [10, с. 121].

Але вже в наступних рядках смуток і розпач переростає в надію. У лексемі місящь проблискують символічні компоненти «оновлення», «переродження», «сприятливі зміни»: Місящзю-князю! $B$ nimbмi будущього, Знать, ти шукаєш Зіля цілющяого... [10, с. 121].

Подибуємо у Франковій поезії і місяць - символ неспокою, перестороги. Такі приховані імпліцитні сенси автор розкриває, використавши мотив сну, дрімоти: Світ дрімає. Блідолищий Місящ̧ь задрімав над ним, - Знать, замкнули в небі двері I поснулося святим [10, c. 118].

Зовсім несподівані семантичні компоненти лексеми «місяць» прочитуємо в поезії «Пісня арештантська», де за допомогою опозиції місяць - сонце автор актуалізує семи темрява - світло, і навіть воля неволя. Місяць тут уособлює пітьму, темряву, ніч, навіть горе: Хто любить місяць - я без сония в'яну, В тюрмі про волю вже й не нагадаю! Сиджу й клену свою судьбу погану, Тих воріженьків, щуо за них страждаю [10, с. 183]. Якщо сонячне світло асоціюється 3 теплом, радістю, життєдайністю, то світло місяця для Івана Франка символ холоду, байдужості, жорстокості. Такі мотиви простежуємо в поезії «Жіноче серце»: Жіноче серие! Чи ти лід студений, Чи запашний, чудовий ивіт весни? Чи світло місячя? Огонь страшенний, Що нищить все? [10, с. 174].

Надзвичайно промовистим символом у поезії Івана Франка виступає «зоря». Цікаво, що образи місяця й зорі в його поезії не перетинаються, функціонують самостійно. Більше того, у поезії «Інша слава сонцю, інша місяцю» розмежовує їх: Інша слава сонцю, інша місяцю, Інша звіздам, щзо на небі сяють, Різна вартість тварей, пса, осла, гадюки, Що сю всеплодючу землю заселяють. Між людьми так само здібні й неподібні, Праведники й грішні різну вартість мають [10, с. 413].

Найчастіше «зоря» у Франковій поезії асоціюється 3 коханою, непереборним і всесильним почуттям: Я б добувсь до тебе через мури й стіни, Я б побив дракони, розметав руїни, Я б здобув всі скарби, щуо їх криє море, I до ніг би твоїх положив, о зоре! [10, с. 230].

Автор не випадково послуговується лексемою зоря, щоб відтворити образ коханої, передати силу і глибину свого почуття. Зоря - символ найвищої досконалості, ідеалу, довершеності. Саме такою для ліричного героя поставала його кохана - земна зоря: Де ви так 
рветесь, куди ви літаєте, Думи-орли? В гості до зірки ви, чень, не бажаєте? К земним зіркам же ви й стежки не знаєте Тут по земли [10, c. 117].

Пестливі, здрібнілі форми «зіронька», «зірничка», «зірка» допомагають тонше розкрити велич і глибину почуття закоханого ліричного героя, виступають символом великої любові: $O$ ні! Являйся, зіронько, мені Хоч в сні! [10, с. 228].

Зоря - це і символ нерозділеного чи втраченого кохання, страждань закоханого, його суму і болю: Неперехідним муром поміж нами Та доля стала! Мов два судна, море Розносить нас між двома берегами, Моя ти ясна, непривітна зоре! [10, с. 213].

Автор часто застосовує паралелізм, що допомагає увиразнити образ коханої, передати ії красу: Золоті зорі в небеснім морі Моргають серед ночі. Та над всі зорі внизу і вгорі - Їі чорні очі [10, с. 222].

Однак зводити зорю в поезії Франка лише до символу коханої це невиправдано звужувати і применшувати універсалізм художнього мовомислення поета. У семантичній структурі цього символу домінантними в поетичному мисленні митця виступають і семи «ідеальний світ», «гармонія».

Віддавна вважалося, що людям дані сонце, місяць і зорі для того, щоб завжди відчувати себе дітьми неба, тимчасово посланими на землю для радощів і страждань, думок про таємне і невідоме, ідеальне й недосяжне [2, с. 113]. Іван Франко не залишався осторонь таких міркувань. У його поезіях лексема зоря наділяється і глибоким філософським смислом. Вона виступає символом краси Всесвіту, найвищої досконалості та гармонії: Тихенько зорі моргають іскристі... Зірниці промінь, мов дитя хлюпочесь В хрустальних водах: голії, безлисті Нависли лози, їм заснути хочесь [10, с. 110].

Зоря - символ вічної животворчої сили, нового життя і світлого духа, який прориває нічну темряву [1, с. 346]. Для Івана Франка - це ще символ добра і боротьба зі злом, яке засіло в душі людській, символ спокою та умиротворення: I в сериі людськім зорі золотаві Мигтять, та ц̌ щука лютая дрімає, I заздрість острі щ̧ипичі виставляе [10, с. 110].

У поетовій уяві зоря асоціюється 3 вічністю. Ця сема $€$ наскрізною в поезії «Смійтесь 3 мене, вічні зорі!..». Автор розгортає перед нами ланцюжок символічних обертонів лексеми зоря: вічність, досконалість, довершеність, високий порив духу, прагнення до вищої гармонії: Смійтесь з мене, вічні зорі! Я нещасний, я черв'як! В мене 
серие, нерви хорі, Не подужають ніяк [10, с. 227].

Зоря - це символ стабільності, ладу, довершеності. Такі експліцитні компоненти простежуємо в поезії «В вагоні»: Тілько $я$ стою, та зорі, Що високо там горять, Не втікають, мов на доказ, Що є в світі стійкість, лад [10, с. 227].

Зоря - світло, що сяє в темряві, символ духу, що виступає проти сил темряви, символ просвітлення, життєдайності, переродження [4, с. 346]: Знов час прийде, коли з погорди пилу Ти отрясешся й ясною звіздою Засяєш людям і підуть з тобою, Серия твою почують давню силу [10, с. 176].

Зірка, зоря - це і щаслива доля, надія, мрія, що живить людину: Вчора тлів, мов Лазар, я В горя домовині - Що ж се за нова зоря Мені блисла нині? [10, с. 92].

Із зорею пов'язують також почуття суму, журби. Поет розгортає і ці символічні компоненти, однак вони в нього набувають яскраво вираженого національного і патріотичного значення, вболівання за долю рідного народу: Над Дунаєм тиха зоря сходить, 3-за мгли сумно на край поглядає. "Чом ти, чом ти рум'янишся, зоре?». «Кров слов'янська так лище вкрасила» [10, с. 92].

Іван Франко досконало ілюструє полісемантичність символу зоря навіть у межах одного тексту. У поезії «Від того дня вже другий рік пройшов» лексема одночасно поєднує в собі символічні компоненти «кохана» та «світло посеред темряви», «духовний провідник», «надія», «доля». Розкрити семантичне наповнення символу авторові допомагає лексема «мгла», що виступає уособленням темних сил, занепаду, апатії, збайдужіння: Отак $i$ я простір думками орю, Так темно в нім, навіки малов густов Закрила доля мою ясну зорю [10, с. 155].

Винятково оригінально митець розкрив образ зорі в поезії «Коляда», наділивши його антиномічністю. Автор подає градацію символу, його розгортання від символу космологічного до глибоко національного, високопатріотичного. Ця поезія написана в дусі фольклорної традиції. А для фольклору символ зорі невід'ємний. Однак Іван Франко відкидає народні трактування цього символу, хоч i відштовхується від них. Як і в фольклорі, у Франковій «Коляді» зірниці уособлюють двох панн, двох сестер: У Господа Бога діточок много, $A$ межи ними не дві зірниці, Не дві зірниці, а дві сестрищзі [10, с. 83].

Але поет не зупиняється на цьому, а подає своє авторське глибинне трактування: Стариа сестриия - руська землиия, Менша 
сестричя - лядська землиця, А рад ти знати, чесний господарю, Коли скінчиться старшої горе? [10, с. 87].

В образі зорі Іван Франко майстерно вмістив образ всієї України, іiї трагічну історію, поневіряння і шлях до волі та свободи.

Ми розглянули тільки маленьку часточку поетичного материка митця. Материка, який не перестає дивувати все новими й новими обріями для досліджень. Бачимо, що Іван Франко завжди і скрізь унікальний та невичерпний. Його поезія - це не просто яскравий приклад поезії, де кожне слово може бути символом, але й промовисте підтвердження його здатності повсюдно проявляти оригінальність.

\section{Література}

1. Багнюк А. Л. Символи українства. Художньо-інформаційний довідник / А. Л. Багнюк. - Тернопіль : Навчальна книга - Богдан, 2010. -512 с.

2. Дмитренко М. Символи українського фольклору : [монографія] / М. А. Дмитренко. - К. : УЦКД, 2011. - 400 с.

3. Жайворонок В. Знаки української етнокультури : [словник-довідник] / В. В. Жайворонок. - К. : Довіра, 2006. - 703 с.

4. Керлот Х. Словарь символов / Х. Керлот. - М., 1994. - 648 с.

5. Ковалик I. Лексика поетичних творів Івана Франка / I. І. Ковалик, І. Д. Ощипко, Л. М. Полюга. - Львів, 1990. - 264 с.

6. Кононенко В. Рідне слово / В. І. Кононенко. - К. : Богдан, 2002. - 303 с.

7. Малиновська А. Лексико-семантичне поле пісня у поетичному світі А. Малишка / А. Малиновська // Мовознавчі студії. - Вип. 2. - Фразеологізм і слово у тексті і словнику (За матеріалами Всеукраїнської наукової конференції на пошану 75-річчя від дня народження Мар'яна Демського). - Дрогобич : «Посвіт», 2010. C. $257-274$.

8. Словник символів культури України / за заг. ред. В. П. Коцура, О. І. Потапенка, М. К. Дмитренка. - К. : Міленіум, 2002. - 260 с.

9. Франкіана Василя Сімовича / упоряд., передмова та примітки М. Білоус i 3. Терлака. - Львів, 2004. - 234 с.

10. Франко І. Вибрані твори : у3-х т. Т.1 : Поезії, поеми / ред. колегія : Скотний В. та інші ; упор. Шалата М. - Дрогобич : Коло, 2004. - 824 с. 